\title{
EFEK EKSTRAK BUNGA KENANGA (Canangium odoratum) SEBAGAI AGONIS PADA RESEPTOR ADRENERGIK- $\beta$ DI PARU TERPISAH MARMUT (Cavia porcellus)
}

\section{(THE EFFECT OF CANANGA FLOWER'S EXCTRACT (Canangium odoratum) AS AGONIS RECEPTOR ADRENERGIC- $\beta$ IN THE GUINEA PIG'S ISOLATED LUNG STRIP)}

\author{
Pherenice Charisti ${ }^{*}$, Retno M Loekito**, Setyawati S Karyono ${ }^{* * *}$ \\ ${ }^{*}$ Program Studi Kedokteran FK Unibraw Malang \\ ** Laboratorium Anatomi Histologi FK Unibraw Malang \\ ${ }^{* * *}$ Laboratorium Farmakologi FK Unibraw Malang
}

\begin{abstract}
The cananga flower (Canangium odoratum) is one of the herbal medicine used for asthma bronchiale. Cananga extract have been proved to relax the isolated guinea pig's tracheal and bronchus smooth muscle. The relaxation of the tracheal smooth muscle could be inhibited by propanolol $10^{-9} \mathrm{M}$, however propanolol $10^{-9} \mathrm{M}$ could not inhibit the relaxation of the bronchial smooth muscle. Therefore the objective of this study is to investigate the effect of cananga extract on relaxation of isolated guinea pig's lung strip through $\beta$ adrenergic receptor. Three different dose of propranolol was used as $\beta$-adrenergic receptor antagonist. This study was an experimental research using guinea pig's isolated lung strip. The control group was given histamine and cananga extract. The first group of treatment was administrated histamine, propanolol $10^{-9} \mathrm{M}$ and cananga extract. The second group of treatment was given histamine, propanolol $10^{-8} \mathrm{M}$ and cananga extract. The third group of treatment was given histamine, propanolol $10^{-7} \mathrm{M}$ and cananga extract. The results of this study showed that cananga extract caused relaxation of lung strip and there was a reduction in the relaxation of lung strip after administration of propanolol. The reduction in relaxation lung strip caused by propranolol inhibition was found to be significant using regression testing. In conclusion, cananga extract works as a partial agonist to $\beta$-adrenergic receptors in bronchial smooth muscle of guinea pigs since the dosage response curve showed shift to the right but it was not paralel.
\end{abstract}

Keyword : cananga extract, relaxation of lung strip, $\beta$-adrenergic receptor.

\section{PENDAHULUAN}

Asma bronkiale, menurut The National Asthma Education Program Expert Panel Report from the National Institutes of Health didefinisikan sebagai penyakit saluran pernapasan akibat adanya proses radang pada jalan napas dan adanya peningkatan respon jalan napas terhadap stimulus. Proses ini menyebabkan terjadinya penyempitan jalan napas yang dapat kembali sempurna secara spontan atau dengan pengobatan $(1,2)$. Meskipun pengetahuan tentang patogenesa dan pengobatan asma bronkiale sudah mapan namun beberapa negara maju melaporkan adanya kenaikan prevalensi, morbiditas dan mortalitas penderita asma bronkiale (3). Penatalaksanaan asma bronkiale secara rasional dan terpadu perlu dipertimbangkan untuk mencegah komplikasi yang bisa berlanjut pada kematian (2). Penatalaksanaan asma bronkiale antara lain dengan obatobat bronkhodilator dan antiinflamasi. Ada banyak bronkhodilator yang saat ini digunakan dengan mekanisme yang berbeda-beda. Di masyarakat banyak pula dikonsumsi bahan alam atau tanaman yang diyakini dapat mengobati penyakit asma, salah satunya adalah bunga kenanga.

Bunga kenanga merupakan tanaman obat yang bermanfaat untuk mengobati penyakit hepatitis, malaria, radang saluran kencing dan asma (4). Telah dibuktikan bahwa ekstrak

Jurnal Kedokteran Brawijaya, Vol. XX, No.3, Desember 2004

Korespondensi: Setyawati S. Karyono; Laboratorium Farmakologi FK Unibraw Malang, Jl. Veteran, Malang 65145. Telp. 0341580993; Fax.0341-564755 bunga kenanga menyebabkan relaksasi otot polos trakea dan paru terpisah marmut, namun belum diketahui mekanisme kerjanya $(5,6)$. Penelitian ini dilanjutkan oleh peneliti lain yang membuktikan bahwa propanolol suatu antagonis reseptor adrenergik- $\beta$ pada dosis 10-9 M mampu menghambat efek relaksasi otot polos trakea akibat pemberian ekstrak kenanga, sehingga diduga ekstrak kenanga bekerja sebagai agonis reseptor adrenergik adrenergik- $\beta$ di otot polos trakea (7). Namun peneliti lain dengan menggunakan sayatan paru (bronkhus) terpisah marmut tidak membuktikan adanya hambatan efek relaksasi ekstrak kenanga oleh propranolol dosis $10^{-9} \mathrm{M}$ (8).

Kontradiksi di atas menarik untuk dikaji lebih lanjut mengingat sebelumnya sudah terbukti ekstrak kenanga dapat menyebabkan relaksasi baik di trakea maupun paru terpisah marmut, padahal bronkhus/ bronkhioli mempunyai struktur yang mirip dengan trakea khususnya pada otot polos yang mampu kontraksi dan relaksasi. Ketidak sesuaian hasil ini kemungkinan karena kedua peneliti tersebut menggunakan dosis propanolol yang sama untuk menghambat efek relaksasi akibat pemberian ekstrak kenanga di trakea dan di bronkhus (paru) terpisah marmut. Untuk lebih memastikan mekanisme relaksasi ekstrak kenanga khususnya di otot polos bronkhus/ bronkhioli, maka perlu dilakukan penelitian dengan menggunakan antagonis reseptor adrenergik- $\beta$ dengan berbagai dosis. Penelitian ini bertujuan untuk membuktikan bahwa ekstrak bunga kenanga berperan sebagai agonis reseptor adrenergik- $\beta$ dalam merelaksasi otot polos bronkus terpisah marmut dengan cara diberi hambatan oleh antagonis reseptor adrenergik- $\beta$. Obat antagonis yang digunakan 
adalah propranolol dengan 3 (tiga) macam dosis sehingga lebih dapat diketahui kemampuannya menghambat ekstrak kenanga.

\section{METODE}

Penelitian ini merupakan penelitian dengan disain true experimental, menggunakan isolated organ. Sayatan paru (lung strip) digunakan untuk isolated organ karena di dalamnya terikut bronkhioli dan merupakan metoda standart yang dapat digunakan untuk percobaan organ terpisah khususnya untuk mengetahui efek agonis terhadap reseptornya di otot polos bronkhioli.

Adapun prosedur penelitian ini adalah mula-mula marmut dimatikan, selanjutnya thoraks dibuka, seluruh jaringan paru diambil kemudian diletakkan pada cawan petri yang telah berisi larutan Kreb's dengan temperatur $35-37^{\circ} \mathrm{C}$ dan dialiri gas karbogen. Untuk preparat sayatan paru (lung strip), potong jaringan paru pada bagian distal (apex) secara diagonal dan tegak lurus terhadap dorsal ventral. Pemotongan diagonal diharapkan bronkhioli terpotong melingkar bukan memanjang. Besar potongan sayatan paru adalah $5 \times 10 \times 2 \mathrm{~mm}$.

Setelah preparasi, sayatan paru segera dimasukkan ke dalam organ bath yang berisi larutan Kreb's dengan temperatur 35-370 C dan terus menerus dialiri gas karbogen. Sayatan paru yang ada di organ bath difixasi dan dihubungkan dengan rekorder di komputer MacLab. Sayatan paru dalam organ bath diinkubasi dulu selama 1-2 jam untuk adaptasi sebelum dilakukan percobaan. Selama inkubasi larutan Kreb's selalu diganti baru setiap 10 menit dan temperatur pada organ bath tetap dipertahankan stabil $(35-370 \mathrm{C})$, serta terus menerus dialiri gas karbogen.
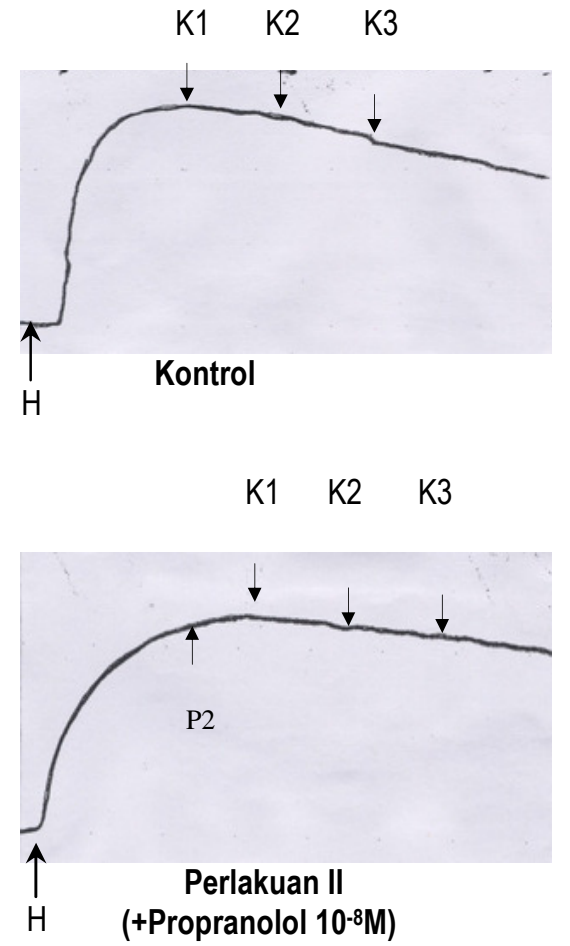

Untuk mendapatkan data kontrol yaitu efek relaksasi dari ekstrak bunga kenanga, mula-mula dilakukan prekontraksi terlebih dahulu dengan pemberian histamin. Dosis histamin untuk prekontraksi besarnya ditentukan pada penelitian pendahuluan yaitu $3.10^{-5} \mathrm{M}$. Setelah terjadi kontraksi ditambahkan ekstrak bunga kenanga untuk mengetahui relaksasinya dengan konsentrasi $0,008 \%, 0,016 \%$ dan $0,032 \%$ yang diberikan secara kumulatif. Sedangkan untuk mendapatkan data perlakuan I dengan hambatan antagonis propranolol, dilakukan hal yang sama dengan kontrol, hanya saja sebelum penambahan ekstrak bunga kenanga diberi propranolol terlebih dulu sebesar $10^{-9} \mathrm{M}$. Untuk perlakuan II dan III, propranolol yang diberikan adalah $10^{-8} \mathrm{M}$ dan $10^{-7} \mathrm{M}$. Selanjutnya dilakukan pengukuran besar relaksasi baik pada kontrol maupun pada perlakuan yang dihambat oleh propranolol. Besar relaksasi yang merupakan penurunan kontraksi akibat pemberian histamin dibuat prosentase terhadap besar kontraksinya dan selanjutnya dilakukan analisa data.

\section{HASIL PENELITIAN}

Dari hasil rekaman pada komputer MacLab dapat diukur besar prekontraksi oleh histamin dan besar relaksasi yang ditimbulkan oleh ekstrak kenanga pada dosis 0,0008\%, 0,0016\%, dan $0,032 \%$ (lihat Gambar 1). Besar relaksasi ini yang merupakan penurunan kontraksi akibat histamin selanjutnya dikonversi dalam prosen terhadap besar prekontraksi. Hasil rerata \% efek relaksasi dari sayatan paru tikus pada kelompok kontrol, perlakuan I, II, dan III dapat dilihat pada tabel 1.
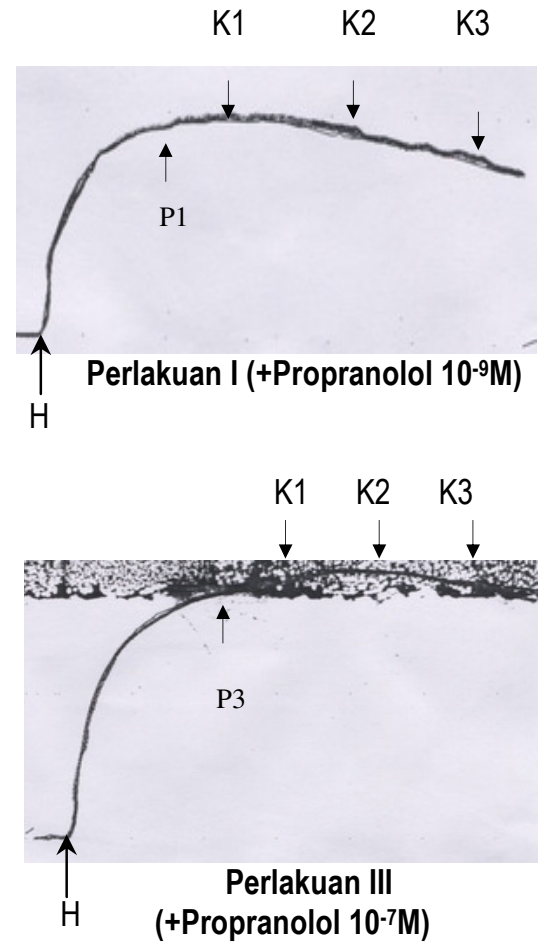

Gambar 1. Efek relaksasi sayatan paru akibat pemberian ekstrak kenanga pada kelompok Kontrol, Perlakuan I, II, dan III 
Tabel 1. Rerata \% efek relaksasi dari sayatan paru tikus setelah pemberian ekstrak kenanga pada tiap kelompok

\begin{tabular}{ccccc}
\hline Dosis & \multicolumn{3}{c}{ Rerata \% relaksasi $(\mathrm{x} \pm \mathrm{SD})(\mathrm{n}=3)$} \\
\cline { 2 - 4 } & Kelompok Kontrol & Kelompok Perlakuan I & Kelompok Perlakuan II & Kelompok Perlakuan III \\
\hline Kenanga 0,008\% & $24,81 \pm 23,58$ & $27,70 \pm 14,28$ & $12,57 \pm 8,48$ & $5,21 \pm 9,02$ \\
\hline Kenanga 0,016\% & $61,50 \pm 43,67$ & $63,88 \pm 31,43$ & $49,58 \pm 32,26$ & $12,50 \pm 21,65$ \\
\hline Kenanga 0,032\% & $126,03 \pm 31,99$ & $113,82 \pm 26,00$ & $88,55 \pm 45,94$ & $25,00 \pm 43,30$ \\
\hline
\end{tabular}

Dari data hasil pengukuran \% relaksasi tersebut dibuat kurva dosis respon ekstrak kenanga dalam menimbulkan efek relaksasi berdasar besar dosis yang diberikan, dimana absis adalah dosis ekstrak kenanga dan ordinat adalah efek relaksasi yang ditimbulkan pada masing-masing dosis. Kurva dosis respon ini dapat dilihat pada Gambar 2 yang terdiri dari kurva kelompok normal, kelompok perlakuan yang dihambat oleh propranolol 10-9 $\mathrm{M}, 10^{-8} \mathrm{M}$ dan $10^{-7} \mathrm{M}$.

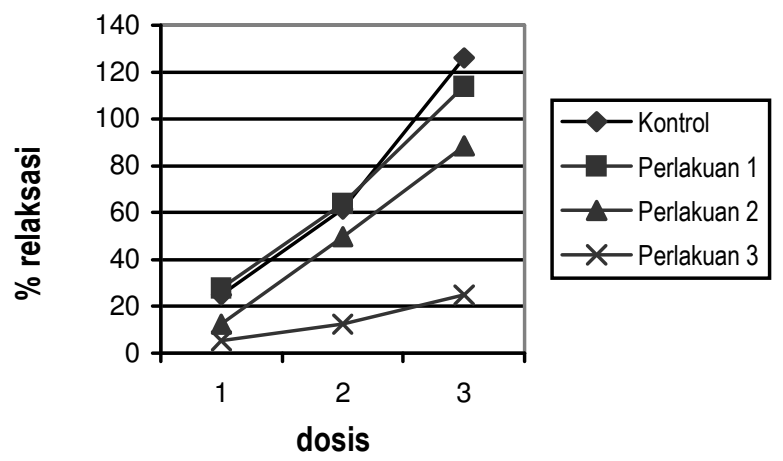

\section{Gambar 2. Kurva Dosis Respon Ekstrak Kenanga Pada Berbagai Kelompok}

Dari hasil di atas dapat diketahui bahwa semakin besar dosis propranolol (perlakuan III) maka gambaran kurva relaksasi ekstrak kenanga semakin landai, hal ini menunjukkan semakin besar hambatan relaksasi yang ditimbulkan ekstrak kenanga.

\section{DISKUSI}

Pada penelitian ini digunakan antagonis adrenergik- $\beta$ (propanolol) yang ditambahkan ke organ bath sebelum pemberian ekstrak kenanga dengan tujuan agar propanolol terlebih dahulu menduduki reseptor adrenergik- $\beta$, sehingga akan menghambat agonis adrenergik- $\beta$ berikatan dengan reseptornya. Apabila ekstrak kenanga memang bekerja sebagai agonis reseptor adrenergik- $\beta$, maka efek relaksasinya dapat dihambat oleh propanolol. Sebaliknya jika ekstrak kenanga tidak bekerja pada reseptor adrenergik- $\beta$ maka efek relaksasinya tidak dapat dihambat oleh propanolol.

Propanolol merupakan antagonis reseptor adrenergik- $\beta$ baik $\beta_{1}$ maupun $\beta_{2}$ (9). Sifat antagonis reseptor artinya propanolol mampu berikatan atau menduduki reseptor adrenergik- $\beta$ tetapi tidak dapat meneruskan sinyal transduksi sehingga aktivitas intrinsik tidak ada dan akhirnya tidak menimbulkan efek farmakologi. Efek yang muncul adalah efek hambatan terhadap agonis sehingga kesempatan agonis menempati reseptornya berkurang dan efeknya berkurang (10).

Pada penelitian ini didapatkan hasil ekstrak kenanga menyebabkan relaksasi (kontrol) dan pada perlakuan dengan penambahan propranolol dosis $10^{-9} \mathrm{M}, 10^{-8} \mathrm{M}$, dan $10^{-7} \mathrm{M}$ terjadi penurunan relaksasi (Gambar 1). Hal ini berarti bahwa ekstrak kenanga yang digunakan dalam percobaan ini memiliki efek relaksasi dan sekaligus dapat dihambat oleh propranolol sesuai dengan hasil penelitian sebelumnya, namun pada dosis yang lebih besar dibanding hambatan pada relaksasinya di trakhea $(5$, $6,7)$.

Pada uji Anova yang dilanjutkan dengan Post Hoc Tests terbukti bahwa ekstrak kenanga dosis 0,032\% memberikan efek relaksasi yang signifikan dibanding dosis $0,008 \%$. Pada uji regresi untuk menguji pengaruh dosis propanolol terhadap efek relaksasi ekstrak kenanga didapatkan koefisien korelasi adalah $-0,739$ dengan tingkat signifikansi 0,003 . Hal ini menunjukkan semakin besar dosis propanolol menyebabkan semakin kecil efek relaksasi ekstrak kenanga (penghambatan propanolol semakin besar). Hal ini semakin mempertegas bahwa ekstrak kenanga bekerja melalui reseptor adrenergik- $\beta$.

Kurva dosis respon ekstrak kenanga (Gambar 2) menunjukkan bahwa pada perlakuan I (penambahan propranolol $10^{-9} \mathrm{M}$ ) tidak berbeda dengan kontrol. Hal ini tampak pada gambar kurva yang berhimpit antara kontrol dan perlakuan I. Sedangkan pada perlakuan II dan III yaitu penambahan propranolol 10-8 M dan $10^{-7} \mathrm{M}$ terjadi pergeseran kurva ke kanan yang tidak sejajar (lebih landai). Pergeseran kurva ini menunjukkan bahwa relaksasi oleh ekstrak kenanga dapat dihambat oleh propranolol. Hal ini berarti relaksasi yang terjadi karena ekstrak kenanga bekerja pada reseptor adrenergik- $\beta$ atau sebagai agonis reseptor adrenergik- $\beta$. Jika ekstrak kenanga tidak bekerja pada reseptor adrenergik- $\beta$ maka efek relaksasinya tidak dapat dihambat oleh antagonis reseptor adrenergik- $\beta$ (propranolol) atau tidak terjadi pergeseran kurva pada kurva dosis respon. Jadi dari hasil penelitian ini dapat disimpulkan bahwa ekstrak kenanga berfungsi sebagai agonis reseptor adrenergik- $\beta$. Selanjutnya dari hasil uji regresi didapatkan persamaan garis pada kontrol adalah $y=-30,443+$ 50,612x; perlakuan I y $=-17,649+43,058 x$; perlakuan II $y=$ $25,750+37,990 x$, dan perlakuan III Adanya perbedaan koefisien $\mathrm{x}$ pada keempat persamaan tersebut menunjukkan bahwa terbentuk kurva yang tidak sejajar antara keempat kelompok tersebut. Ketidaksejajaran ini berarti bahwa ekstrak kenanga tidak hanya bekerja pada reseptor adrenergik $\beta$ tetapi bekerja juga melalui mekanisme lain dalam merelaksasikan otot polos bronkus paru atau disebut agonis parsial. Hal ini diduga disebabkan karena ekstrak kenanga yang dipakai adalah ekstrak kasar sehingga ada bahan aktif yang bekerja pada reseptor adrenergik- 
$\beta$ dan ada pula bahan lain yang bekerja pada reseptor lain di otot polos bronkhus yang di paru. Apabila ekstrak kenanga bekerja sebagai full agonis maka terbentuk kurva yang bergeser ke kanan dan sejajar. Bertolak dari temuan ini bahwa ekstrak kenanga berfungsi sebagai agonis parsial pada reseptor adrenergik- $\beta$, maka mekanisme kerja ekstrak kenanga dalam merelaksasikan otot polos bronkus paru juga dapat melalui mekanisme lain. Kemungkinan mekanisme lainnya adalah sebagai antihistamin, inhibitor protein kinase C, inhibitor enzim fosfodiesterase, aktivator kanal ion $\mathrm{K}^{+}$, dan antikholinergik $(11,12,13,14,15)$.

Dari hasil penelitian dapat disimpulkan bahwa efek relaksasi otot polos oleh ekstrak kenanga mampu dihambat oleh antagonis reseptor adrenergik- $\beta$ (propanolol). Peningkatan dosis propanolol menyebabkan penurunan efek relaksasi atau semakin meningkat dosis propanolol semakin menurun efek relaksasi yang ditimbulkan oleh ekstrak kenanga. Jadi ekstrak kenanga terbukti merelaksasi otot polos bronkus paru melalui reseptor adrenergik- $\beta$ atau berfungsi sebagai agonis reseptor adrenergik- $\beta$, namun karena yang digunakan ekstrak kasar maka yang terbukti adalah sebagai agonis parsial pada reseptor adrenergik- $\beta$ di otot polos bronkhus paru.

\section{KESIMPULAN}

Berdasarkan hasil penelitian dapat disimpulkan bahwa ekstrak bunga kenanga menyebabkan relaksasi sayatan paru terpisah marmut dan mekanisme kerjanya sebagai agonis parsial pada reseptor adrenergik- $\beta$ di paru.

\section{SARAN}

1. Perlu penelitian lebih lanjut untuk membuktikan mekanisme kerja selain melalui reseptor adrenergik- $\beta$

2. Perlu penelitian lanjutan mengenai selektivitas ekstrak kenanga terhadap reseptor adrenergik adrenergik $\beta_{1}$ dan $\beta_{2}$.

3. Perlu penelitian lanjutan tentang zat aktif yang terkandung dalam bunga kenanga yang berperan dalam merelaksasikan otot polos bronkus paru marmut.

\section{DAFTAR PUSTAKA}

1. Fish J, Peters S. Asthma: Clinical Presentation and Management. In: Fishman's Pulmonary Diseases and Disorders $3^{\text {rd }}$ Ed. Singapore: McGraw-Hill companies, Inc. 1998; 757-774

2. Murray P, Corbridge T. Pharmacotheraphy of Acute Asthma. Dalam: Jesse B. Hall et all. Acute Asthma: Assesment and Management. Singapore: McGraw-Hill companies, Inc. 2000; 139-145

3. Sundaru H. Penatalaksanaan Asma Masa Kini. (http://www.papdi.or.id. Diakses 3 Mei 2004). 2002

4. Hembing. Sehat dengan Kenanga. (http://www.infobunga.com. Diakses 8 Oktober 2002). 2002

5. Saraswati D. Pengaruh Ekstrak Bunga Kenanga Terhadap Kontraktilitas Trakea Terpisah Marmut. [Tugas Akhir]. Malang: Fakultas Kedokteran Universitas Brawijaya. 2000

6. Melani S. Pengaruh Ekstrak Bunga Kenanga Terhadap Kontraktilitas Bronkus Paru Terpisah Marmut. [Tugas Akhir]. Malang: Fakultas Kedokteran Universitas Brawijaya. 2000

7. Halim N. Efek Ekstrak Bunga Kenanga Terhadap Trakea Terpisah Marmut Melalui Reseptor adrenergik Adrenergik $\beta$. [Tugas Akhir]. Malang: Fakultas Kedokteran Universitas Brawijaya. 2001

8. Sulamit T. Efek Ekstrak Bunga Kenanga Terhadap Relaksasi Bronkus Paru Terpisah Marmut Setelah Pemberian Propanolol. [Tugas Akhir]. Malang: Fakultas Kedokteran Universitas Brawijaya. 2002

9. Setiawati A, Gan S. Penghambat Adrenergik. Dalam: Sulistia G. Ganiswarna (Ed). Farmakologi dan Terapi. Jakarta: Bagian Farmakologi Fakultas Kedokteran Universitas Indonesia; 1995; 81-86.

10. Setiawati A, SB Zunilda, Suyatna FD. Pengantar Farmakologi. Dalam: Sulistia G. Ganiswarna (Ed). Farmakologi dan Terapi. Jakarta: Bagian Farmakologi Fakultas Kedokteran Universitas Indonesia; 1995; 18-19

11. Chand N, Sofia RD. Histamine. In: D. Raeburn and M. A. Giembycz. Airways Smooth Muscle: Neurotransmitters, Amines, Lipid Mediators and Signal transduction. Birkhauser Verlag Berlin; 1995; 132-141

12. Hirst SJ. Airway Smooth Muscle. In: M. Maureen Dale, John C. Foreman, Tai-ping D. Fan. Textbook of Immunopharmacology 3rd Ed. England: Oxford Blackwell Scientific Publications. 1994; 107-119.

13. Anderson G. Adrenaline and Noradrenaline. In: D. Raeburn and M. A. Giembycz. Airways Smooth Muscle: Neurotransmitters, Amines, Lipid mediators and Signal transduction. Berlin: Birkhauser Verlag; 1995; 2-34

14. Burt. Smooth Muscle. (http://www@human.physiol.arizona.edu. Diakses 22 Juni 2004). 2004

15. Darmansjah, Setiawati A, Gan S. Obat Otonom. Dalam: Sulistia G. Ganiswarna (Ed). Farmakologi dan Terapi. Jakarta: Bagian Farmakologi Fakultas Kedokteran Universitas Indonesia; 1995; 31-37 

